\section{Special Collection of Perspectives on Broadening Participation}

\section{Kenneth D. Gibbs, Jr.*}

Division of Training, Workforce Development, and Diversity, National Institute of General Medical Sciences, Bethesda, MD 20892

$\mathrm{T}$ is collection is envisioned as a follow-up to the 2016 Special Issue on Broadening Participation (Gibbs and Marsteller, 2016a) and invited leaders with a demonstrated track record of effective action in this area at the student training, program development, institutional leadership, and policy levels to share the wisdom they have developed from years of practice and to put forward provocative ideas to stimulate the community to action. The Special Issue included the perspectives of funding agencies such as the National Institutes of Health (Valantine et al., 2016), the National Science Foundation (James and Singer, 2016), the U.S. Department of Agriculture (Parker and Wagner, 2016), and the Howard Hughes Medical Institute (Asai and Bauerle, 2016), and more than 25 research articles. These perspectives allow individuals whose dayto-day work underpins much of this empirical research the opportunity to respond, and focus the life science community on how to move forward in meeting the critical national need of ensuring that it can cultivate and harness the talents of people from all backgrounds (Gibbs and Marsteller, 2016b).

\section{REFERENCES}

Asai, D. J., \& Bauerle, C. (2016). From HHMI: Doubling down on diversity. CBE-Life Sciences Education, 15(3), fe6. doi: 10.1187/cbe.16-01-0018

Gibbs, K. D. Jr., \& Marsteller, P. (Eds.) (2016a). Special Issue: Broadening Participation in the Life Sciences. CBE-Life Sciences Education, 15(3).

Gibbs, K. D. Jr., \& Marsteller, P. (2016b). Broadening participation in the life sciences: Current landscape and future directions. CBE-Life Sciences Education, 15(3), ed1. doi: 10.1187/cbe.16-06-0198

James, S. M., \& Singer, S. R. (2016). From the NSF: The National Science Foundation's investments in broadening participation in science, technology, engineering, and mathematics education through research and capacity building. CBE-Life Sciences Education, 15(3), fe7. doi: 10.1187/cbe.16-01-0059

Parker, J. E., \& Wagner, D. J. (2016). From the USDA: Educating the next generation: Funding opportunities in food, agricultural, natural resources, and social sciences education. CBE-Life Sciences Education, 15(3), fe5. doi: 10.1187/cbe.16-01-0052

Valantine, H. A., Lund, P. K., \& Gammie, A. E. (2016). From the NIH: A systems approach to increasing the diversity of the biomedical research workforce. CBE-Life Sciences Education, 15(3), fe4. doi: 10.1187/ cbe.16-03-0138
CBE Life Sci Educ September 1, 2018 17:ed1 DOI:10.1187/cbe.18-07-0114

*Address correspondence to: Kenneth D. Gibbs (Kenneth.gibbs@nih.gov).

C) 2018 K. D. Gibbs. CBE-Life Sciences Education (C) 2018 The American Society for Cell Biology. This article is distributed by The American Society for Cell Biology under license from the author(s). It is available to the public under an AttributionNoncommercial-Share Alike 3.0 Unported Creative Commons License (http:// creativecommons.org/licenses/by-nc-sa/3.0).

"ASCB $®$ " and "The American Society for Cell Biology $\circledR^{\prime \prime}$ are registered trademarks of The American Society for Cell Biology. 